\title{
ACADEMIC RELATIONS BETWEEN DEBRECEN AND VIENNA: EXEMPLIFIED BY EDUARD BÖHL AND SÁNDOR VENETIANER
}

\author{
KARL SCHWARZ * \\ University of Vienna
}

\begin{abstract}
The study seeks to investigate the relationship between Theological Faculty of Debrecen Reformed College and the Protestant Theological Faculty at University of Vienna. The counter-movements against modern, or so-called liberal theology brought Eduard Böhl from Vienna and Ferenc Balogh into a shared theological camp. The former followed the German-Dutch confessionalist Pietist of Reformed faith the letter became the leading figure of New-Orthodoxy movement of Debrecen. Both professors were keen on educating and training students with a view to respect and love the traditional doctrines, faith expressions of the church. Their endeavoured to put their students into significant jobs where influence could be exerted. This paper shows light on how Böhl sought to manage a former student, Sándor Venetianer's carreer so as to continue the kind of theology that the famous professor of dogmatics also promoted.
\end{abstract}

Keywords: Eduard Böhl, Sándor Venetianer, Ferenc Balogh, Pietism, new-orthodoxy, Debrecen and Vienna

\section{Protestant Theological Academy in Vienna (1821)}

For my contribution to this symposium, I have chosen to elucidate the findings of a major scientific historical project examining the 'Academic relations between Debrecen and Vienna' (Schwarz 2015). I shall focus on the relationship between the Viennese professor for Calvinistic theology Eduard Böhl and his Hungarian pupil, Sándor Venetianer, attesting to the axis that the two formed between Debrecen and Vienna. I should start by briefly explaining the background to the Protestant Theological Academy of Vienna before we go any further. The Academy was founded in 1819 and opened its doors in 1821. It was originally housed in a schoolyard in the heart of Vienna, which quickly proved too small, meaning that the Academy very quickly had to relocate-to a palace very close to the Hungarian Chancery (nowadays the Hungarian Embassy) in the street where the Protestant Theological Faculty is now once again found (I., Schenkenstrasse 8-10), behind the nowadays

* $\quad$ KARL SCHWARZ (PhD 1983, University of Vienna) is a Professor of Practical Theology, at Department of Practical Theology and Psychology of Religion, University of Vienna, Austria. Email: karl.schwarz@univie.ac.at. 
'Burgtheater'. The Academy was established for political reasons. The Austrian Education Authority had issued a blanket ban on foreign study following the Wartburg Festival (18 October 1817). The first political assassination in 1819 prompted Prince Metternich to close the borders in an attempt to halt the spread of the feared revolutionary influence of the German universities. This very heavily curtailed the peregrinatio academica previously enjoyed by Hungarian theologians. To compensate for this, a theological academy was opened in Vienna with the primary aim of steering its students towards Habsburg patriotism and commandeering them as future 'teachers of the people'. In his speech to celebrate the opening of the Academy on 2 April 1821, the Viennese Superintendent and Konsistorialrat Johann Wächter (1767-1827) highlighted its significance and precisely described its mission as instilling in its students 'the spirit of true love for their fatherland, unconditional obedience towards the law, and faithful, unwavering allegiance to their Prince and the entire noble ruling dynasty' (Wenrich 1831: 147). The Academy was faced with the task of establishing a standing for itself as an Austrian alternative to studying at the very free-thinking German universities (Jena, Halle, Göttingen and Heidelberg) (Schwarz 2007). This represented such a monumental undertaking that it could never have come anywhere close to achieving this aim. The Hungarian students responded to the Academy with great scepticism and overt, politically motivated reservations. Above all, studying in the Habsburgs' capital and residence city would be a costly affair. The first cohort of 39 students commenced their studies in Vienna in 1821-26 from Hungary and twelve from Transylvania — of whom I shall cite just one: István Aranyi (1793-1864), who went on to become a Professor of Theology in Debrecen (Gaál 2012: 8391). [Lecture at the Symposium at the Partium Christian University in Oradea / Nagyvárad / Großwardein, 23 November 2018]

The teaching corps was gathered from applicants from the circle of domestic grammar school professors who had passed the selection exams. One promising candidate for the Reformed Chair had withdrawn his application at the last minute: István Szoboszlai Pap (1790-1864). His appointment might well have made the Academy more attractive to Reformed students. However, a Reformed pastor called János von Patay (1778-1854) from Zips/Szepes/Spiš was appointed instead (Schwarz/Wagner 531), who made a name for himself primarily as an exegete. Teaching was conducted mainly in German, with the exception of Latin for the exegetical and systematic classes in Reformed theology.

Another Reformed theologian at the Academy, Gabriel Szeremlei (18071867), returned 1856 to the High School in Sárospatak after just a few years (Schwarzand and Wagner 1997: 531). After that, the Professorship remained vacant for many years due to the lack of Reformed students enrolling from 
Hungary. It was not until 1864 that the Chair was reoccupied-by the young Eduard Böhl (1836-1903), a private lecturer just 28 years old from Basle.

\section{Eduard Böhl}

Böhl was appointed in 1864 to bolster the confessional ranks in the faculty (Schwarz 2016). A letter from the Austrian envoy in Berlin dated 22 February 1864 reveals the motivation behind the two appointments in 1863 and 1864 of the practologist Johann Michael Szeberiny (1825-1915) and the Reformed dogmatist Böhl-to counter the 'unionist efforts in the Austrian Protestant Church' but also 'the emerging tendency towards steering the confessional direction more determinedly and forging a subservient attitude towards the State [...] under the pretext of separating the Church from the State in the name of autonomy' (Schwarz 2008: 205).

The State clearly had a vested political interest in opposing liberal theology, with its ecclesio-political intentions to separate the State from the Church. One professor forthrightly relativized the confessional obligation and was moved at a superintendents' assembly to make statements that the Ministry believed disqualified him from 'representing Protestant theology' by questioning the need for compliance with the confessions. Eduard Böhl adhered precisely to the requirements in question and duly complied with the Ministry's expectations-already during his inaugural lecture on 11 April 1864 on the Confessio Helvetica Posterior (Second Helvetic Confession) as the confessional script of the Reformed Church, of which he also obtained a commentated edition (Vienna 1866). A few weeks later, the two synods of the Evangelical Churches A.C. and H.C. convened in joint sessions (28 May-9 July 1864). Böhl had been elected to represent his faculty in the synod H.C. and thus witnessed this Austrian 'union of synods' first-hand. He unhesitatingly proved his theological orientation, vehemently emphasising the confessional position and arguing against any synods that 'under the mantle of collegiality, attempt to introduce mass rule in the Churches and with the aid of these masses eliminate Christ and Christianity, seeking to replace them with the result of our modern-day universal education: the spirit of civilisation that is science' (Ev. Sonntagsbote 1864: 472). This was noted and seemingly also perceived as a theological challenge (Ev. Sonntagsbote 1864: 472).

If we take a slightly closer look at his curriculum vitae (Schirrmacher 1995: 203-224), we will see that it is remarkable in several ways. Born to parents of mixed religion-Lutheran and Catholic - the maternal line of his father's side of the family could be traced back to Melanchthon's sister, Margaretha Schwarzerd. Böhl himself adopted his father's Lutheran confession. After an excellent secondary education at renowned grammar schools in Hamburg and Berlin, an encounter with Ernst Wilhelm Hengstenberg (18021869), the Editor-in-chief of the Protestant Church newspaper, proved monumental. As a dedicated campaigner against rationalism, Hengstenberg reinforced Böhl's desire to study in Halle, where he was greatly influenced by 
August Tholuck (1799-1877) and Johannes Wichelhaus (1819-1858). The latter invited him to Elberfeld in 1856, where he met Hermann Friedrich Kohlbrügge (1803-1875) for the first time. He had already been introduced to the programme of divine inspiration and infallibility of the Holy Scripture by Wichelhaus. He also learned of an independent Reformed congregation in Elberfeld that opposed the compulsory union imposed by the State in Prussia (Heinrichs, 102 f.). This must have particularly impressed and challenged him, as he then continued his studies as a Kohlbrïgge fellow under Franz Delitzsch (1813-1890) in Erlangen. There, he was awarded the title D.Phil. in 1860 for his doctoral thesis on the Aramaisms in the Salomon's Book ('De Aramaismis libri Kohelet'. Dissertatio historica et philologica, quo librum Salomoni vindicare conatur). The work he presented in this thesis opposed the accepted findings of the history of religion at that time and asserted Salomon's authorship. He augmented his D.Phil. with a Lic.theol. in Basle on the basis of his work on Isaiah 24-27 (Vaticinium Jesaiae, Lipsiae 1861). Furthermore, he converted to the Reformed Church, as Kohlbrügge had 27 years earlier, and reinforced his allegiance to the Kohlbrügge School-consisting of the triumvirate Wichelhaus, Böhl, and Adolf Zahn (1834-1900)—by marrying the daughter of his Elberfeld mentor, Anna Kohlbrügge ( $\dagger 1873)$.

His writings focused exclusively on the Old Testament. In 1862, he completed his major theological work, Twelve Messianic Psalms, an Ancient-Church Christological Interpretation of the Old Testament, in which he attributed the Book of Psalms to King David. His meticulously christological interpretation of the Old Testament and his adherence to the unity of the Old and New Testaments shifted him to the theological fringe, which consequently cost him the Old Testament Chair in Basle. However, this is how he ended up in Vienna in 1864-not as a Biblical academic, but instead as the Chair of Reformed Theology. His appointment provoked vehement protest, particularly from the Lutheran systematician Richard Adelbert Lipsius (1830-1892), who made no secret of his disdain for this 'Hyper-Hengstenbergianer'. He carried the consequences and left Vienna after only a few years in 1865 (Schwarz/Wagner, 531). Böhl remained, however, even if he was a complete outsider as a Reformed confessionalist at a predominantly liberal faculty that tended to favour the union.

Böhl's lecturing duties stretched beyond Reformed dogmatics and symbolism to include Biblical Theology, Apology of Christianity, Religious Philosophy and Pedagogy, which saw him teach both Reformed and Lutheran students. In 1872, for example, he published a work on General Pedagogy (1872), drawn from his teachings in that field. One review (Ev. Reformierte Kirchenzeitung 1872: 375-9) sincerely praised his 'very open stance towards belief in revelation' and 'faithfully biblical spirit'. His point of departure for pedagogy was considered particularly noteworthy, i.e. the 'plight of man through original sin' 
and his attack on the 'pedagogical Phariseeism' of modernity. When several students left the Church A.C. for the Reformed Church (H.C.) due to Böhl, this caused an enormous scandal, which earned him the accusation of proselytism and only cemented his pronounced status as an outsider in the teaching corps (Böhl 1891: 13). However, Böhl functioned as the confessional fulcrum for the Reformed Church, in which the Czechs made up the vast majority. He was considered, as one of his seniors put it, as a man who introduced his students 'faithfully to the understanding of our confession and its trueness to the Bible', 'teaching them reverence for the sovereign Word of God to place all their trust in the free Grace of God through Jesus Christ' while 'carrying the entire Reformed Church of Austria in his heart'. His advocate furthered this praise by citing Böhl's demand at the 1864 General synod for a 'determined sustenance of the Reformed Criterion' (Zur Erinnerung, 24).

Böhl's teaching was particularly important for the Reformed students from Bohemia and Moravia, who formed a veritable Böhl School ('Böhlovci') (Filipi 1997: 453-66). He regularly gathered his students for seminars in various parsonages, including in Vienna, and composed newsletters that disseminated his theological communications beyond the classroom. He focused keenly on Kohlbrügge's theology. Students from Hungary also sometimes took part in these seminars.

\section{Böhl's Radiance Towards Hungary}

Amongst the circle of students, he addressed in this way was Alexander/Sándor Venetianer (Böhl 1891: 15, 22; Balke 2001: 98). A theological seminar group had also formed in Hungary at the initiative of Josef von Erdős (18561946) (Balke 2001: 90), who would later become a Professor of Theology in Debrecen, which engaged with Böhl's and Kohlbrügge's approach and broadened its reception. The same aim was pursued in this case-to put prevailing theological liberalism in its place (Kovács 2014: 61-64).

The following theologians all studied with Böhl, who subsequently dispatched them to Elberfeld and Holland to further their studies and undertake ministerial training: Pastor Sigmund Keck (1861-1944) in Cservenka/Slavonia (Balke 2001: 93); Pastor Károly Rácz (1842-1925) in Bánfalva (Csohány 1987/2004: 162; Balke 2001: 96; Kósa 2004: 461-4), who published a church newsletter and acted as the press officer for the seminar group; Erdős had also completed ministerial training in Elberfeld (1882) and worked as a pastor in Pancsova (in southern Hungary, nowadays Serbia) and Új-Sóvé (in Bačka, nowadays Ravno Selo in Serbia) before acquiring higher academic titles in Vienna 1888/1891 (Schwarz and Wagner 1997: 517) and earning great merit with his translations of the Heidelberg Catechism (1884) and the Confessio Helvetica Posterior (1907) (Nagy 1966: 138-40; Juhász 2010: 76). 
Both these Reformational sources were completely repelled by the prevailing liberal theology in Hungary. He and his son Karl von Erdős (18871971) are considered to have been major protagonists in Kohlbrügge's circle in Hungary (Csohány 1973; Kósa 2004: 463; Kovács 2018).

\section{Alexander Carl Theodor Venetianer}

But let us turn now to Venetianer, who had a rather special status. We know a fair bit about his main credentials (Kövér 2012). He was of Jewish descent as the son of the Rabbi Albert Venetianer (1831-1897) and his wife Regina, née Stern (1829-1892), who lived in Fadd, Tolna County, in Hungary, where he was born on 17 June 1853 .

After finishing grammar school in Kecskemét, we know from his own curriculum vitae (1864) that he spent several months in Pest, where he was 'repeatedly inspired by encounters with committed Christians to research the truth behind Christianity'. He had already abandoned his domestic Jewish traditions, which eventually led to a breakdown in his relationship with his father. In autumn 1871, he started studying philosophy in the guise of Natural Science Disciplines in Vienna, 'but did not gain any satisfaction' from this.

\section{Baptism and Theological Studies}

In Spring 1873, he moved to Prague, where he lamented to one of his friends from Pest, the Jewish missionary Karl Andreas Schönberger (1841-1924) (Kövér 2017: 470), the 'strife' that tormented him and ultimately motivated him to get baptised (10 August 1873) in the Lutheran Church in Pragueand to switch his course of study. The Jewish Mission ('Judenmission') by members of the Scottish Free Church was acting since 1839 in Budapest (Kool 1993: 98; Kovács 2006: 173; Kovács 2016: 19; Hausmann 2018).

Venetianer returned to Vienna and enrolled at the Faculty of Protestant Theology on 3 October 1873 (Taufrath), but transferred to Basle the very next year, where his extraordinary philological skills really stood out. To the chagrin of his Old Testament lecturer at Basle, Hans Conrad von Orelli (1846-1912), in spring 1875 he left Basle to resume studying in Vienna (enrolling there 5 April 1875-Taufrath).

Orelli wrote to Böhl to alert him to Venetianer's special talent, even explicitly requesting him to take him under his wing (Archiv Böhl Nr. 25). This is then precisely what happened, as he found his way into Böhl's closest circle of students.

Venetianer paid testament to his beneficial influence in his curriculum vitae, although without mentioning his transition from the Augsburg to the Helvetic confessions, which happened under Böhl's tutelage. 


\section{Examination in Debrecen and Pastoral Activity in Banat, Bačka and Trieste}

In 1877 , Venetianer took his pro candidatura examination. Debrecen was renowned as the central command of the Orthodox fight against liberalism (Kovács 2014: 61). He must surely have wholeheartedly agreed with the Debrecen Confession drafted during those years (Debreceni Hitvallás-1875), as this was very akin to the theological insight instilled in him by Böhl. His Reformed Bishop sent him to perform pastoral duties in Jász-Nagykun-Szolnok County, then to Bihar County, and he worked as a chaplain in the parishes in Túrkeve-not without getting into conflict with the local pastor (Kovács 2017: 164-8)—and Oradea.

After taking his pro ministerio examination in Pančevo in Torontál County, he was ordained by Superintendent Valentin Révész (1816-1891) on 11 May 1878. There, he married Danube-Swabian Maria Barth, who died very prematurely $(\dagger 1889)$, leaving him with three minor children. His second wife, Jolantha née Hartmann, died five years later ( $† 1894)$, after which he married her elder sister. The couple had moved to Bačka in 1880, to the Reformed parish of Újsóvé (formed in 1786) halfway between Vrbas and Novi Sad, before he was finally elected as the pastor for the Reformed congregation in Trieste on 6 March 1884 (Patzelt 1999: 100; Venetianer 1887).

\section{Publishing Activity in Debrecen}

In a post scriptum to his curriculum vitae, Venetianer refers to his publishing activity in a very characteristic way: 'I put my meagre powers to the best use by not only speaking but also writing in order to spread the truth, the recognition of which is what liberated me', in the following positively aligned Hungarian church magazines: the Evangyéliomi Protestáns Lap = Evangelical Protestant Paper in Debrecen, edited by Prof. Ferenc Balogh (1836-1913); the Debreceni Protestáns Lap $=$ Debrecen Protestant Paper, edited by Prof. Sámuel Tóth (1838-1899); the Magyar Protestáns Egyházi és Iskolai Figyelmező = Hungarian Protestant Church and School Herald, edited by Imre Révész (1826-1881); and the two papers edited by Pastor Márton Czelder (1833-1889) Magyar Protestáns Egyházi és Iskolai Figyelő = Hungarian Protestant Church and School Observer and Vasárnap = Sunday in Felsőbánya (Csohány 1974/2004: 236-49; Kovács 2014: 64-66; Kovács 2017 : 151-169).

The Church historian Ferenc Balogh played an important role in the history of Hungarian theology. He is considered the 'Leader of Debrecen neoOrthodoxy' (Kovács 2010: 41; Kovács 2017: 156) and, as such, was the 'most well-known Debrecen professor of his era' (Kovács 2006: 158). He corresponded with both Böhl (Kovács 2018) and Venetianer. 


\section{Academic Ambitions in Debrecen}

On 14 April 1887, Venetianer wrote a letter from Trieste to his Viennese mentor (Archiv Böhl Nr. 50) advising him that the body of professors in Debrecen would support his interest in assuming the Old Testament chair. He revealed that Balogh had encouraged him to apply. The recognition of his licential thesis on 'The interpretation of the Book of Isaiah' in Vienna (29 June 1887) was an important step on the prescribed academic career path. It should be pointed out here that the fees this incurred caused him financial hardship. Apart from that, his application in Debrecen was unsuccessful. However, Balogh predicted even better prospects for him the following year, in 1888, for the New Testament Chair.

Nonetheless, Venetianer strongly declined Böhl's enquiry as to whether he might not wish to work towards a professorship in Vienna, writing that he 'didn't have the slightest intention' of doing that-only to go back on this unequivocal statement just a short time thereafter (Archiv Böhl Nr. 50). While working as a pastor in a colony of Reformed Swabian peasants in Rohrbach near Odessa (nowadays Novosvitlivka, Ukraine), a centre of pious stundism (Roemmich), 1887-1889 (Amburger 1998: 501), he informed Böhl of his change of heart. He said that he could now see that he 'could become far more effective' at a school like that in Debrecen and would now be glad to be allowed to work there-after all, he knew what it was lacking. He would not be afraid to fight for the opportunity, but he did not wish to force himself upon them. He eventually asked Böhl and the New Testament expert Albrecht Vogel (1822-1890) to support his application (Archiv Böhl Nr. 50). But this attempt also failed, with him being ranked second behind his friend Josef Erdős, because of his 'difficult nature' (Kovács 2018).

\section{Academic Plans in Debrecen and Vienna}

The prospect of a career in Debrecen motivated Venetianer in 1895 to launch a theological investigation into the resurrection of Jesus, with which he intended to intervene in the dispute between the rationalist professor Mór Ballagi (1815-1891) in Budapest and the Orthodox-Calvinist pastor Lajos Filó (1828-1905) in Debrecen, which had been raging since the 1860s (Kovács 2006: 182; Kovács 2016: 72) and secure his doctorate at the same time. However, he never got beyond gathering the material, as his plans for the doctorate proved to be unrealistic. This led him to return to Bačka and resume his former pastor's role in Újsóvé, having stayed in contact by sending funds. There, he got involved in revising a Reformed hymn book. As word started to spread that he was magyarising his German congregation to preserve their Reformed confession and prevent them from joining the Lutheran Church (Fata 1993), this stirred up antisemitic resentment (Ev. Reform. Blätter 1895: $100)$. 
When he discovered that Böhl was holding fast to his 'lofty plan' to put him forward for the Chair in Vienna, he retorted in a letter to him that he could not speak of any 'literary endeavour' on his own part. He claimed that he had not produced anything substantial enough to be of interest to academic circles. But on 11 July 1899, he recognised that, if it were a 'calling from the Lord', then he would have to acquiesce and take on this work, even if it would certainly involve him having to learn. But he had no real faith in this endeavour, feeling that he was 'unworthy of taking your [Böhl's] place'. He believed he did not possess the necessary knowledge and felt that Böhl should not be mistaken in thinking that he could offer anything more than diligence and good intentions (Archiv Böhl Nr. 50).

\section{Editing the Bible}

The British Bible Society's decision to commission Venetianer to help revise Károlyi's translation of the Bible into Hungarian demonstrated to him that his Biblical academic expertise was valued during his final years of activity (Venetianer 1900). His critique of the previous editing work conducted by the Bible Society had clearly motivated him to get involved so as to steer it in the right direction. In a letter to Böhl, he offered an insight into this editing work, naming not only the Bible experts György Radácsi (1846-1928) from Sárospatak and József Dicsőfi (1859-1920) from Debrecen, but also three further contributors from Pest and Cluj, although adding that they were 'not taken seriously, as they were so weakly and insufficiently qualified' for the job. He described Radácsi as well-versed in modern literature and also very devoted, 'but so docile that I had no difficulty convincing him'. In contrast, he wrote that the Bible academic from Debrecen was 'haughty in the knowledge that he was well-learned and knew more than the others'.

He agreed that the man knew a great deal, but considered him too onesided, tending to swear by the latest observations and hung up on the duty to demonstrate academic progress as editors. He insisted on favouring the Septuaginta over the Masoretic Text, whereas Venetianer successfully argued that the Hebraica veritas be restored throughout. He said that as they had not completed the work, they would have to redistribute the work in order to finish the editing in June 1901.

Venetianer indicated that Professor Böhl 'had gone to some trouble' to persuade the Bible Society to commission this editing work on the Bible and expressed the hope that the new translation would meet the justified expectations of the Church. The work was completed in 1908. It was Venetianer's final academic output, and he certainly did not live to witness its publication, as he already passed away in 1902-at the age of just 49. He left behind a widow caring for seven children. 


\section{Following in Böhl's Footsteps in Vienna}

In the annals of faculty's history, Venetianer is considered to have been Böhl's clear favourite to succeed him when he retired prematurely from lecturing on health grounds in 1899, after seventy semesters (Balke 2001: 98). Böhl considered him to be 'eminently qualified for a theological professorship' (Böhl 1891: 22). In his grandiose speech, he recommended him heartily to the rest of the faculty based on what he deemed Venetianer's special linguistic assets in being able to lecture in German, Czech, and Hungarian and digest literature in all these languages. In addition, he was confident that Venetianer could provide the intellectual and theological skills required for the Chair. But Böhl was unable to push through his recommendation. The college of professors objected resolutely and appointed the candidate that Böhl had ruled out: Bohumil Mareš (1851-1901), a Czech pastor who was just about to submit his doctoral thesis on the Reformed Doctrine of Gracious Choice in the faculty. Even if Mareš was never appointed, due to his death during the process, this nonetheless clearly signified that the college of professors had distanced themselves from Böhl. Disappointed in his failed academic career, in 1902 Venetianer suffered a fatal stroke, which was followed by the death of his teacher and mentor Eduard Böhl one year later. The Chair subsequently remained vacant until 1913, temporarily occupied by the Viennese pastor and member of Church Council H. C. Carl Alphons Witz-Oberlin (1845-1918).

\section{Bibliography}

Amburger E (1998) Die Pastoren der evangelischen Kirchen Rußlands vom Ende des 16. Jahrhunderts bis 1937. Erlangen.

Balke W (2001) Eduard Böhl. Hoogleraar te Wenen en schoonzoon van dr. H.F. Kohlbrügge. Zoetermeer.

Csohány J (1973) Magyar protestáns egyháztörténet 1849-1918. Debrecen.

Csohány J (1974/2004) A XIX. Századi Magyar református ébredés debreceni ága. In Tanulmányok Debrecen és a reformátusság múltjáról. Debrecen, pp. 236-249.

Csohány J (1987/2004) Rácz Károly (1842-1925) lelkipásztor élete és munkássága. In Tanulmányok Debrecen és a reformátusság múltjáról. Debrecen, pp. 162-174.

Filipi P (1997): Die Schüler Eduard Böhls in Böhmen und Mähren. In Schwarz KW/ Wagner F (Hgg) Zeitenwechsel und Beständigkeit. Beiträge zur Geschichte der Evangelisch-Theologischen Fakultät in Wien 1821-1996. Wien, pp. 453-466.

Gaál B (2012) Kistanszékből nagy egyetem. DRHE-HITEK. Debrecen. 
Hausmann G (2018) Erweckung-Mission-Soziales Engagement im Umfeld von Erzherzogin Maria Dorothea. Conference Paper Oradea/Nagyvá$\mathrm{rad} /$ Großwardein 22 November 2018.

Hausmann J (2009) Mária Dorottya nádorné kora és a zsidómisszió. In András Korányi (Hg) Megújulás és megmaradás. Fabiny Tibor-emlékkönyv. Budapest. pp. 231-240.

Heinrichs WE (1989) Freikirchen-eine moderne Kirchenform. Entstehung und Entwicklung von fünf Freikirchen im Wuppertal. Gießen.

Juhász T (2010) Mirabilis est cursus verbi Dei! Die Entwicklung des Helvetischen Bekenntnisses in Ungarn und Siebenbürgen. In Fata M, Schindling A (Hgg) Calvin und Reformiertentum in Ungarn und Siebenbürgen. Helvetisches Bekenntnis, Ethnie und Politik vom 16. Jahrhundert bis 1918 (= RStT 155). Münster. pp. 63-78.

Kövér A (2012) A Venetianer fivérek 'Főrabbi, református lelkész és katolikus pap’ Egy Morvaországból származó, Magyarországon elő zsidó család története a 19.sz. második felében. In Koltai K $(\mathrm{Hg})$ A szivnek van két rekesze. Tanulmánykötet Prof. Dr. Schweitzer József tiszteletére, 90. születésnapja alkalmából. Budapest. pp. 465-486.

Kövér A (2017) Die Venetianer-Brüder, available online on www.izrael-immanuel.net/?p=4081; Langfassung: http://izraelim.net/MP3/Venetianer\%20fiv\%C3\%A9rek\%20(n\%C3\%A9met\%C3\%BCI).pdf

Kool AM (1993) God Moves in a Mysterious Way. The Hungarian Protestant Foreign Mission Movement (1756-1951). Utrecht.

Kósa L (2004) Studentenaustausch zwischen Elberfeld und Debrecen. In KZG 17(*): 459-499.

Kovács A (2003/06) The History of the Free Church of Scotland's Mission to the Jews in Budapest and its Impact on the Hungarian Reformed Church: 1841-1914, Diss. Edinburgh 2003 (= SiGC 140), Frankfurt 2006.

Kovács A (2010) Hitvédelem és egyháziasság. A debreceni új ortodoxia vitája a liberális teológiával. Budapest.

Kovács A (2014) Die Antwort der Debrecener neuen Orthodoxie auf den theologischen Liberalismus in Ungarn. In ZNThG 21(*): 47-68.

Kovács A (2016) Nemzetközi kálvinizmus Európa perifériáin: magyar és skót Protestáns kapcsolatok a 19. században. Budapest.

Kovács T (2017) Die Alliierten. Der österreichische reformierte Pietismus begegnet der ungarischen Neoorthodoxie. In Lášek JB, Kónya P (Hgg) Reformation in Mitteleuropa. Beiträge zur Reformationsgeschichte in den Ländern der Donaumonarchie. Prag, pp. 151-169.

Kovács T (2018) The Defender of Faith. The Correspondence between Ferenc Balogh, Father of New Orthodoxy Movement and Eduard Böhl, a Reformed Pietist Professor of Dogmatics from Vienna, Conference Paper Oradea/Nagyvárad/Großwardein, 23 November 2018. 
Nagy B (1966) Geschichte und Bedeutung des Zweiten Helvetischen Bekenntnisses in den osteuropäischen Ländern. In Staedtke J (Hg) Glauben und Bekennen. Vierhundert Jahre Confessio Helvetica Posterior. Zürich, pp. 109-202.

Patzelt H (1999) Evangelisches Leben am Golf von Triest. Geschichte der evangelischen Gemeinde in Triest mit Abbazia, Görz, Fiume und Pola. München.

Roemmich H (1978) Stundisten-Evangeliumschristen-Baptisten. Ihr Ursprung und ihr Weg zu einer protestantischen Kirche in der UdSSR. In Schnurr J (Hg) Heimatbuch der Deutschen aus Russland. Stuttgart, pp. 64-85.

Schirrmacher T (1995) 'Festwerden im Glauben an Christum': Leben und Werk Eduard Böhls. In Festschrift zum 25jährigen Bestehen der Staatsunabhängigen Theologischen Hochschule Basel (= Fundamentum 3), pp. 137-163.

Schwarz KW (2007) Evangelische Theologie zwischen kultureller Nachbarschaftshilfe und volksdeutschem 'Sendungsbewusstsein'. Die Wiener Protestantisch-theologische Lehranstalt/Fakultät und ihre Bedeutung für den Donau- und Karpatenraum. In Danubiana Carpathica 1(*): 89-112.

Schwarz KW (2008) Ein Sieg des 'Neuluthertums'. Die Berufung des Theologieprofessors Johann Michael Seberiny. In Wiener Jahrbuch für Theologie [WJTh] 7(*):197-208.

Schwarz KW (2015) Debrecen-Wien: Von István Szoboszlai Pap bis Zsigmond Varga. In Studia Debreceni Teológiai Tanulmányok 7(2): 27-37.

Schwarz KW (2016) 'Zur entschiedene[n] Wahrung des reformierten Criteriums'. Eine fakultätsgeschichtliche Annäherung an den Systematiker Eduard Böhl. In Heil U, Schellenberg A (Hgg) Frömmigkeit. Historische, systematische und praktische Perspektiven (= WJTh 11). Göttingen, pp. 233-255.

Schwarz KW (2019) '[E]minently qualified for a theological professorship': Der Absolvent der Wiener Fakultät Alexander Venetianer und seine fehlgeschlagenen akademischen Ambitionen. In Heil U, Klein A, Schellenberg A (Hgg) Autor und Autorität. Historische, systematische und praktische Perspektiven (= WJTh 12). Göttingen, pp. 181-194.

Schwarz KW, Wagner F (1997) Zeitenwechsel und Beständigkeit. Beiträge zur Geschichte der Evangelisch-Theologischen Fakultät in Wien 1821-1996. Wien.

Wenrich JG (1831) Johann Wächter als Mensch, als Diener des Staates und der Kirche. Wien.

\section{Primary Sources}

Böhl E (1864) Rückblicke auf die erste evangelische Generalsynode Österreichs im Jahre 1864. In Ev. Sonntagsbote für Kirche, Schule und Haus. pp. 454-496.

Böhl E (1872) Allgemeine Pädagogik. Wien.

Böhl E (1891) Recent Dogmatic Thought Among the Protestants in AustriaHungary. In PRR 2(5): 1-29. 
Böhl E (2008) Archiv: Amsterdam Vrije Universiteit. Historisch Documentatiecentrum voor het Nederlands Protestantisme: Collectie Nr. $108=$ Archiv Böhl. In Geppert K (Hg) Inventar des Archivs von Prof. Dr. Eduard Böhl, available online for consultation on http://www.hdc.vu.nl/Images/108_Eduard_Boehl_tcm215-13710.pdf [20.5.2016].

Taufrath M (1871-1874) Kurze Nachrichten über die k.k. evangelisch-theologische Fakultät in Wien [...] mit Nachträgen aus den Studienjahren 1871/72-1873/74. Venetianer A (1884) Lebenslauf. AEvOKR NAR Fasz. 299, Zl. 889/884.

Venetianer A (1887) Die Evangelisch-Reformierte Kirche Cristo Salvatore (vormals S. Silvestro) zu Triest. Beitrag zur Geschichte des Evangeliums in Triest. TriestLeipzig.

Venetianer A (1900) Az új Ószövetség. Összehasonlitó bibliai tanulmány. Szeged.

*** (n.d.) Zur Erinnerung an den von Herrn Hermann von Tardy [...] im Namen seiner und etlicher anderer böhmischen reformirten Gemeinden zum Heiligen Osterfeste 1865 unserer Gemeine erstatteten Besuch. Elberfeld. 